\title{
Analisa Model Evaporasi dan Evapotranspirasi Menggunakan Pemodelan Matematika pada Visual Basic di Kabupaten Maros
}

\author{
(Analysis of Evaporation and Evapotranspiration Model Using Mathematical \\ Modeling on Visual Basic in Maros Regency)
}

\author{
Ahmad Fausan $^{1 *}$, Budi Indra Setiawan ${ }^{1}$, Chusnul Arif ${ }^{1}$, Satyanto Krido Saptomo ${ }^{1}$ \\ ${ }^{1}$ Departemen Teknik Sipil dan Lingkungan, Fakultas Teknologi Pertanian, Institut Pertanian Bogor \\ Kampus IPB Dramaga, PO BOX 220, Bogor, Jawa Barat, Indonesia \\ *Penulis Korespondensi: ahmad_fausan@apps.ipb.ac.id
}

\section{ABSTRACT}

The approach to calculating evaporation and evapotranspiration, both potential and actual, varies widely. The models used to estimate the amount of evapotranspiration, particularly at the Maros Climatology Station, Maros Regency, South Sulawesi. Evaporation models use the Penman, Priestley, Bruin, and Valiantzas models while evapotranspiration models use the Penman, Hargreaves, Jensen-Haise, Penman-Monteith, Radiation, Turc, and Makkink models, where all of these methods use climate data, such as are the minimum temperature (Tn), maximum temperature (Tx), air temperature (Ta), average humidity $(R H)$, rainfall $(R)$, duration of sun exposure $(S S)$, and maximum wind speed $(U)$ in calculations using Visual basic program in Microsoft Excel in the form of code. Thus, it is necessary to conduct an analysis of the suitability of the model to the results of the observations in order to find out which model is suitable according to the results of the largest coefficient of determination $\left(R^{2}\right)$. Based on the results of the model suitability analysis, a selected model was obtained, namely the Valiantzas model with a value of 0.980 in the evaporation calculation and the Jensen-Haise model, namely 0.889.

Keywords: evaporation, evapotranspiration, visual basic

\section{PENDAHULUAN}

Perubahan iklim global membawa konsekuensi besar terhadap ketersediaan air dalam bidang pertanian. Pertumbuhan tanaman akan baik jika kebutuhan tanaman akan unsur hara, udara dan air dapat terpenuhi secara optimal. Seperti halnya tanaman yang kehilangan air karena evaporasi. Proses evaporasi telah dikenal sejak dahulu, yaitu untuk membuat garam dengan cara menguapkan air dengan bantuan energi matahari dan angin dengan mempertimbangkan estimasi.

Estimasi Evaporasi diperlukan dalam berbagai macam masalah dalam hidrologi, agronomi, kehutanan dan perencanaan sumber daya lahan, seperti neraca air komputasi, pengelolaan irigasi, prakiraan aliran sungai, investigasi kimia danau, pemodelan ekosistem, dll. Dari semua komponen siklus hidrologi, evaporasi mungkin yang paling sulit diperkirakan karena hingga interaksi yang kompleks antara komponen-komponen sistem daratan, tumbuhan, dan atmosfer (Singh 1997). Model Evaporasi yang mencakup istilah energi dan aerodinamis yang tersedia (model kombinasi) memberikan perbandingan terbaik dengan evaporasi standar deviasi diukur di Kabupaten Maros.

Berbagai model evaporasi yang dikaji dalam penelitian ini adalah Model Penman, Priestley, Bruin, dan 
JSIL | Fausan dkk. : Analisa Model Evaporasi dan Evapotranspirasi Menggunakan Pemodelan Matematika pada

Valiantzas. Selain Evaporasi, data evapotranspirasi suatu wilayah merupakan data yang penting untuk perencanaan pengembangan sumberdaya air dan pengaturan waktu irigasi pada wilayah tersebut. Evapotranspirasi dapat menggambarkan jumlah air yang hilang dari badan air karena adanya vegetasi. Jenis vegetasi mempengaruhi jumlah evapotranspirasi secara signifikan. Karena air ditranspirasikan melalui daun yang mengalir dari akar, tumbuhan yang akarnya menancap dalam ke bawah tanah mentranspirasikan air lebih banyak. Evapotranspirasi merupakan jumlah air yang dikembalikan lagi ke atmosfer dari permukaan tanah, badan air,dan vegetasi oleh adanya pengaruh faktor-faktor iklim dan fisiologis vegetasi (Rokhma 2008). Dalam menentukan nilai evapotranspirasi perlu diperhatikan dua istilah yaitu evapotranspirasi aktual (ETa) dan evapotranspirasi potensial (ETp). Evapotrasnpirasi potesial menggambarkan kebutuhan lingkungan, sekumpulan vegetasi, atau kawasan pertanian untuk melakukan evapotranspirasi yang ditentukan oleh beberapa faktor, seperti intensitas penyinaran matahari, kecepatan angin, luas daun, temperatur udara, dan tekanan udara. Evapotranspirasi potensial juga menggambarkan energi yang didapatkan oleh kawasan tersebut dari matahari. Di sisi lain, transpirasi sebanding dengan seberapa banyak karbon yang diserap oleh kawasan vegetasi karena transpirasi juga berperan perpindahaan $\mathrm{CO}_{2}$ dari udara ke daun.

Berbagai model evapotranspirasi yang dikaji dalam penelitian ini adalah Model Penman, Hargreaves, JensenHaise, Penman-Monteith, Radiasi, Turc, dan model Makkink. Model Penman dan Penman-Monteith relatif rumit, karena membutuhkan parameter iklim yang banyak dan konversi satuan yang kompleks. Model Penman membutuhkan lima parameter iklim yaitu: suhu, kelembaban relatif (relative humidity), kecepatan angin, tekanan uap jenuh (saturation vapor pressure), dan radiasi netto (Doorenbos 1977). Pada model Hargreaves, Jensen-Haise, Radiasi, Turc dan model Makkink merupakan model evapotranspirasi yang sederhana, dengan data yang dibutuhkan hanya dua parameter iklim yaitu suhu dan radiasi matahari (Capece 2002).

Tujuan penelitian adalah menguji tiga model evaporasi dan sembilan model evapotranspirasi untuk mendapatkan model yang efisien yaitu perhitungan sederhana dan mempunyai ketelitian yang tinggi.

\section{METODOLOGI}

Penelitian ini dilakukan pada tanggal 25 September 2020 (Evaporasi) dan 2 Oktober 2020 (Evapotranspirasi). Penelitian ini (Evaporasi dan Evapotranspirasi) dibutuhkan data sekunder yang dihasilkan dari Badan Meteorologi, Klimatologi, dan Geofisika (BMKG). Data sekunder yang dibutuhkan adalah temperatur minimum (Tn), temperatur maksimum (Tx), temperatur udara $(\mathrm{Ta})$, kelembaban ratarata $(\mathrm{RH})$, curah hujan (R), lamanya penyinaran matahari (SS), dan kecepatan angin maksimum (U). Penelitian ini menggunakan program visual basic pada Microsoft Excel berupa kodingan. Secara umum, diagram alir pelaksanaan penelitian disajikan pada Gambar 1 . 


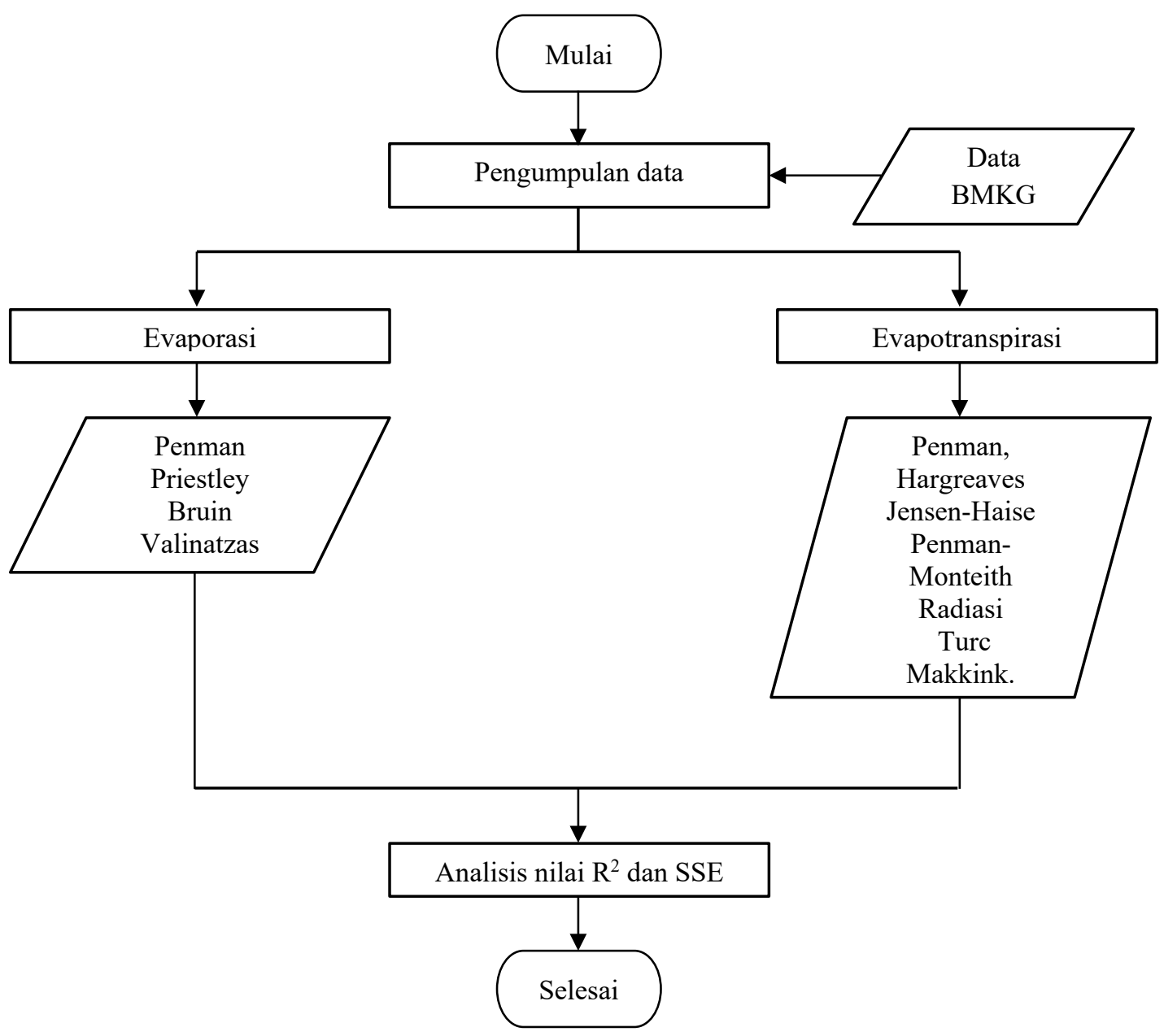

Gambar 1 Diagram Alir Pelaksanaan Penelitian

\section{Evaporasi}

Berdasarkan data-data yang dihasilkan dari BMKG, selanjutnya akan didapatkan nilai parameter extraterrestrial radiation $(\mathrm{Ra})$ dan global radiation (Rs). Nilai global radiation dapat mewakili keseimbangan antara radiasi matahari yang masuk dan sipantulkan. Extraterrestrial radiation ini di bagian atas atmosphere ini dapat dihitung sebagai fungsi dari garis lintang situs dan hari dalam setahun. Data iklim yang dibutuhkan sebanyak satu tahun (365 hari) yaitu 1 Januari 2019 - 31 Desember 2019. Model Evaporasi yang digunakan adalah model Penman, Priestley, Bruin, dan Valiantzas. Persamaan umum yang digunakan keempat model tersebut dapat dilihat pada Persamaan berikut.

(Penman, 1948)

$$
E_{o}=\frac{1}{\Delta+\gamma}\left(\frac{R_{n} \Delta}{\rho \lambda}+\gamma \delta e f_{U}\right)
$$

Keterangan:

$E_{o} \quad=$ Evaporasi (m/hari)

$\mathrm{R}_{\mathrm{n}} \quad=$ net radiation $\left(\mathrm{MJ} \mathrm{m}^{-2} \mathrm{~d}^{-1}\right)$

$\Delta \quad=$ kemiringan tekanan uap $\left(\mathrm{kPa}{ }^{\circ} \mathrm{C}^{-1}\right)$

$\rho=$ densitas udara $\left(1000 \mathrm{~kg} \mathrm{~m}^{-3}\right)$

$\lambda=$ panas penguapan laten $\left(=2.45 \mathrm{MJ} \mathrm{kg}^{-1}\right)$

$\gamma \quad=$ konstanta psikometrik uap $\left(\mathrm{kPa}{ }^{\circ} \mathrm{C}^{-1}\right)$

Se $\quad=$ defisit tekanan uap $(\mathrm{kPa})$ 
JSIL | Fausan dkk. : Analisa Model Evaparasi dan Evapotranspirasi Menggunakan Pemadelan Matematika pada

$\mathrm{f}_{\mathrm{U}} \quad=$ konduktansi aeordinamis ( $\mathrm{m}$ hari ${ }^{-1} \mathrm{kPa}^{-1}$ )

$\mathrm{U}=$ kecepatan angin $(\mathrm{m} /$ detik $)$

(Priestley, 1972)

$\mathrm{E}_{\mathrm{o}}=\frac{\alpha \mathrm{A} \Delta}{\rho \lambda(\Delta+\gamma)}$

Keterangan:

$E_{o} \quad=$ Evaporasi (m/hari)

$a \quad=$ net radiation $\left(\mathrm{MJ} \mathrm{m}^{-2} \mathrm{~d}^{-1}\right)$

$\Delta \quad=$ kemiringan tekanan uap $\left(\mathrm{kPa}{ }^{\circ} \mathrm{C}^{-1}\right)$

$\rho \quad=$ densitas udara $\left(1000 \mathrm{~kg} \mathrm{~m}^{-3}\right)$

$\lambda=$ panas penguapan laten $\left(=2.45 \mathrm{MJ} \mathrm{kg}^{-1}\right)$

$\gamma \quad=$ konstanta psikometrik uap $\left(\mathrm{kPa}{ }^{\circ} \mathrm{C}^{-1}\right)$

de $\quad=$ defisit tekanan uap $(\mathrm{kPa})$
(Bruin, 1979)

$\mathrm{E}_{\mathrm{o}}=\frac{\mathrm{A} \Delta}{\rho \lambda(\mathrm{a} \Delta+\mathrm{b} \gamma)}$

Keterangan:

$E_{o} \quad=$ Evaporasi (m/hari)

A $=$ energi available $\left(\mathrm{MJ} \mathrm{m}^{-2} \mathrm{~d}^{-1}\right)$

$a \quad=$ konstanta $(=0.85)$

$B \quad=$ konstanta $(=0.63)$

$\Delta \quad=$ kemiringan tekanan uap $\left(\mathrm{kPa}^{\circ} \mathrm{C}^{-1}\right)$

$\rho \quad=$ densitas udara $\left(1000 \mathrm{~kg} \mathrm{~m}^{-3}\right)$

$\lambda=$ panas penguapan laten $\left(=2.45 \mathrm{MJ} \mathrm{kg}^{-1}\right)$

$\gamma \quad=$ konstanta psikometrik uap $\left(\mathrm{kPa}^{\circ} \mathrm{C}^{-1}\right)$

(Valiantzas, 2006)

$\mathrm{E}_{\mathrm{o}}=0.047 \sqrt{T_{a}+9.5}-2.4\left(\frac{R_{s}}{R_{a}}\right)^{2}+0.09\left(T_{a}+20\right)\left(1-\frac{\mathrm{RH}}{100}\right)$

Keterangan:

$E_{o} \quad=$ Evaporasi (m/hari)

$\mathrm{R}_{\mathrm{S}} \quad=$ radiasi global $\left(\mathrm{MJ} \mathrm{m}^{-2} \mathrm{~d}^{-1}\right)$

$\mathrm{R}_{\mathrm{a}} \quad=$ radiasi luar angkas $\left(\mathrm{MJ} \mathrm{m}^{-2} \mathrm{~d}^{-1}\right)$

$\mathrm{T}_{\mathrm{a}} \quad=$ suhu rata-rata $\left({ }^{\circ} \mathrm{C}\right)$

$\mathrm{RH}_{\mathrm{a}}=$ kelembaban rata-rata harian (\%)

\section{Evapotranspirasi}

Sama halnya dengan evaporasi, data-data yang dihasilkan dari BMKG akan didapatkan nilai parameter extraterrestrial radiation ( $\mathrm{Ra})$ dan global radiation ( $\mathrm{Rs}$ ). Nilai $\mathrm{Ra}$ dan $\mathrm{Rs}$ didapatkan berdasarkan kodingan pada visual basic di Microsoft Excel. Nilai Ra dan Rs akan digunakan pada model Penman-Monteith (Penman Modifikasi).
Penelitian ini akan dibandingkan antara model Penman-Monteith dengan sembilan metode lainnya (Tabel 1). Sembilan model Evapotranspirasi yang digunakan adalah model Blaney-Cridlle, Linacre, Kharrufa, Remanenko, Hagreaves, Makkink, Turc, JensenHaise, dan Penman. Evaluasi efisiensi model dengan cara membandingkan hasil perhitungan model. Evapotranspirasi dikaji berdasarkan data parameter iklim dengan durasi sepuluh tahun terakhir yaitu tahun $2000-2009$. Hasil yang didapatkan menunjukkan bahwa hubungan antara evapotranspirasi harian hasil pengukuran langsung dengan model kurang baik yakni nilai $\mathrm{R}^{2}$ sekitar 0,64. Persamaan umum yang digunakan kesembilan model tersebut dapat dilihat pada Persamaan berikut. 
Tabel 1 Perbandingan Beberapa Model Evapotranspirasi

\begin{tabular}{clcccccc}
\hline No & Model & T & Rs & RH & u & Panjang Hari & Faktor Tanaman \\
\hline 1 & Blaney-Cridlle & X & & & & & \\
2 & Linacre & X & & & & & \\
3 & Kharrufa & X & & & & & \\
4 & Remanenko & X & & X & & & \\
5 & Hargreaves & X & X & & & & \\
6 & Makkink & X & X & & & & \\
7 & Turc & X & X & & & & \\
8 & Jensen-Haise & X & X & & & & \\
9 & Penman & X & X & X & X & X & \\
10 & Penman-Monteith & X & X & X & X & X & X \\
\hline
\end{tabular}

Tabel 2 Konversi Beberapa Unit Satuan Radiasi Matahari

\begin{tabular}{lccccc}
\hline \multirow{2}{*}{ Unit } & \multicolumn{3}{c}{ Unit } & Eqivalen evaporasi \\
\cline { 2 - 6 } & $\mathrm{MJ} / \mathrm{m}^{2}$ hari & $\mathrm{J} / \mathrm{cm}^{2}$ hari & $\mathrm{W} / \mathrm{m}^{2}$ & $\mathrm{cal} / \mathrm{m}^{2}$ hari & $\mathrm{mm} /$ hari \\
\hline $\mathrm{MJ} / \mathrm{m}^{2}$ hari & 1.000 & 100.000 & 11.600 & 23.900 & 0.408 \\
$\mathrm{cal} / \mathrm{cm}^{2}$ hari & 0.042 & 4.187 & 0.485 & 1.000 & 0.017 \\
$\mathrm{~W} / \mathrm{m}^{2}$ & 0.086 & 8.640 & 1.000 & 2.060 & 0.035 \\
$\mathrm{~mm} /$ hari & 2.450 & 245.000 & 28.400 & 58.500 & 1.000 \\
\hline
\end{tabular}

\section{Model Blaney-Criddle}

Model ini merupakan model yang paling sederhana hanya membutuhkan satu parameter lingkungan yaitu suhu udara dengan menggunakan persamaan (5).

$\mathrm{ET}_{\mathrm{p}}=\mathrm{p}\left(0.4 \mathrm{~T}_{\text {mean }}+8\right)$

Keterangan:

$\mathrm{ET}_{\mathrm{p}}=$ evapotranspirasi potensial (mm/hari) $\mathrm{p} \quad=$ persentase rata-rata harian penyinaran matahari

$\mathrm{T}_{\text {mean }}=$ suhu udara rata-rata harian $\left({ }^{\circ} \mathrm{C}\right)$

Nilai $p$ tergantung dari posisi lintang tempat pengukuran dan waktu pengukuran. Nilai $p$ masingmasing lokasi dapat dilihat pada Tabel 3 . Apabila posisi lintang tempat pengukuran tidak tercantum dalam daftar tersebut maka perlu dilakukan interpolasi. 
JSIL | Fausan dkk. : Analisa Model Evaparasi dan Evapotranspirasi Menggunakan Pemadelan Matematika pada Visual Basic di Kabupaten Maras

Tabel 3 Nilai p Pada Masing-masing Garis Lintang

\begin{tabular}{|c|c|c|c|c|c|c|c|c|c|c|c|c|c|}
\hline \multirow{2}{*}{$\begin{array}{c}\text { Garis } \\
\text { Lintang }\end{array}$} & $\mathrm{U}$ & Jan & Feb & Mar & Apr & Mei & Juni & Juli & Agt & Sep & Okt & Nov & Des \\
\hline & S & Juli & Agt & Sep & Okt & Nov & Des & Jan & Feb & Mar & Apr & Mei & Juni \\
\hline 60 & & 0.15 & 0.20 & 0.26 & 0.32 & 0.38 & 0.41 & 0.40 & 0.34 & 0.28 & 0.22 & 0.17 & 0.13 \\
\hline 55 & & 0.17 & 0.21 & 0.26 & 0.32 & 0.36 & 0.39 & 0.38 & 0.33 & 0.28 & 0.23 & 0.18 & 0.16 \\
\hline 50 & & 0.19 & 0.23 & 0.27 & 0.31 & 0.34 & 0.36 & 0.35 & 0.32 & 0.28 & 0.24 & 0.20 & 0.18 \\
\hline 45 & & 0.20 & 0.23 & 0.27 & 0.30 & 0.34 & 0.35 & 0.34 & 0.32 & 0.28 & 0.24 & 0.21 & 0.20 \\
\hline 40 & & 0.22 & 0.24 & 0.27 & 0.30 & 0.32 & 0.34 & 0.33 & 0.31 & 0.28 & 0.25 & 0.22 & 0.21 \\
\hline 35 & & 0.23 & 0.25 & 0.27 & 0.29 & 0.31 & 0.32 & 0.32 & 0.30 & 0.28 & 0.25 & 0.23 & 0.22 \\
\hline 30 & & 0.24 & 0.25 & 0.27 & 0.29 & 0.31 & 0.32 & 0.31 & 0.30 & 0.28 & 0.26 & 0.24 & 0.23 \\
\hline 25 & & 0.24 & 0.26 & 0.27 & 0.29 & 0.30 & 0.31 & 0.31 & 0.29 & 0.28 & 0.26 & 0.25 & 0.24 \\
\hline 20 & & 0.25 & 0.26 & 0.27 & 0.28 & 0.29 & 0.30 & 0.30 & 0.29 & 0.28 & 0.26 & 0.25 & 0.25 \\
\hline 15 & & 0.26 & 0.26 & 0.27 & 0.28 & 0.29 & 0.29 & 0.29 & 0.28 & 0.28 & 0.27 & 0.26 & 0.25 \\
\hline 10 & & 0.26 & 0.27 & 0.27 & 0.28 & 0.28 & 0.29 & 0.29 & 0.28 & 0.28 & 0.27 & 0.26 & 0.26 \\
\hline 5 & & 0.27 & 0.27 & 0.27 & 0.28 & 0.28 & 0.28 & 0.29 & 0.28 & 0.28 & 0.27 & 0.27 & 0.27 \\
\hline 0 & & 0.27 & 0.27 & 0.27 & 0.27 & 0.27 & 0.27 & 0.27 & 0.27 & 0.27 & 0.27 & 0.27 & 0.27 \\
\hline
\end{tabular}

Ket : U : Lintang Utara, $\mathrm{S}$ : Lintang Selatan

\section{Model Linacre}

Metode ini hanya membutuhkan informasi parameter suhu. Model ini dapat dibuat berdasarkan Persamaan (6).

$$
\begin{aligned}
& \mathrm{ET}_{\mathrm{P}}=\frac{\left(500 \mathrm{~T}_{\mathrm{m}} /(100-\mathrm{A})\right)+15\left(\mathrm{~T}_{\text {mean }}-\mathrm{T}_{\mathrm{d}}\right)}{80-\mathrm{T}_{\text {mean }}} \\
& \mathrm{T}_{\mathrm{m}}=\mathrm{T}_{\text {mean }}+0.006 \mathrm{~h} \ldots \ldots \ldots \ldots \ldots \ldots \ldots \ldots \ldots \ldots \ldots \ldots \ldots \ldots
\end{aligned}
$$

Keterangan:

$$
\begin{aligned}
\mathrm{ET}_{\mathrm{p}}= & \text { evapotranspirasi potensial } \\
& (\mathrm{mm} / \mathrm{hari}) \\
\mathrm{A} & =\operatorname{lintang}(\text { degree }) \\
\mathrm{h} & =\text { elevasi }(\mathrm{m}) \\
\mathrm{T}_{\text {mean }}= & \text { suhu udara rata-rata }\left({ }^{\circ} \mathrm{C}\right) \\
\mathrm{T}_{\mathrm{d}}= & \text { suhu udara pada titik } \\
& \text { embun }\left({ }^{\circ} \mathrm{C}\right)
\end{aligned}
$$

\section{Model Kharrufa}

Model ini mirip dengan model Blaney-Cridlle yang hanya membutuhkan satu data cuaca dan parameter. Nilai evapotranspirasi model ini diberikan persamaan (8) berikut:

$$
\mathrm{ET}_{\mathrm{p}}=0.34 \mathrm{p}\left(\mathrm{T}_{\text {mean }}\right)^{1.3}
$$

Keterangan:

$$
\begin{aligned}
\mathrm{ET}_{\mathrm{p}}= & \text { evapotranspirasi potensial } \\
& (\mathrm{mm} / \text { hari }) \\
\mathrm{p} & =\text { persentase rata-rata harian } \\
& \text { penyinaran matahari }(\text { Tabel } 2) \\
\mathrm{T}_{\text {mean }}= & \text { suhu udara rata-rata harian }\left({ }^{\circ} \mathrm{C}\right)
\end{aligned}
$$

\section{Model Remanenko}

Model ini membutuhkan dua data cuaca, yaitu suhu rata-rata harian dan kelembaban relatif. Adapun persamaan (9) model remanenko sebagai berikut:

$$
\mathrm{ET}_{\mathrm{p}}=0.00018\left(25+\mathrm{T}_{\text {mean }}\right)^{2}(100-R H)
$$

Keterangan:

$\mathrm{ET}_{\mathrm{p}}=$ evapotranspirasi potensial (mm/hari)

$\mathrm{T}_{\text {mean }}=$ suhu udara rata-rata harian $\left({ }^{\circ} \mathrm{C}\right)$

$\mathrm{RH}=$ kelembaban relatif $(\%)$

Apabila RH tidak diketahui, maka bisa diprediksi dengan menggunakan data suhu udara rata-rata ( $\left.\mathrm{T}_{\text {mean }}\right)$ dan suhu udara pada titik embun $\left(\mathrm{T}_{\mathrm{d}}\right)$ dengan persamaan sebagai berikut: 
$\mathrm{RH}=\frac{\mathrm{e}^{\mathrm{o}}\left(\mathrm{T}_{\mathrm{d}}\right)}{\mathrm{e}^{\mathrm{o}}\left(\mathrm{T}_{\text {mean }}\right)}$

Keterangan:

$\mathrm{e}^{\circ}(\mathrm{T})=$ tekanan uap jenuh

Nilai $\mathrm{e}^{\circ}(\mathrm{T})$ dapat dihitung dengan persamaan 11 atau 12 dengan mengganti nilai $\mathrm{T}$ dengan suhu masing-masing.

$\mathrm{e}_{2}=33.8639\left[\left(0.00738 \mathrm{~T}_{\text {maks }}+0.8072\right)^{8}-\right.$ $\left.0.000019\left|1.8 \mathrm{~T}_{\text {maks }}+48\right|+0.001316\right]$

$\mathrm{e}_{1}=33.8639\left[\left(0.00738 \mathrm{~T}_{\min }+0.8072\right)^{8}-\right.$

$\left.0.000019\left|1.8 \mathrm{~T}_{\min }+48\right|+0.001316\right]$

\section{Model Hargreaves}

Hagreaves ini cukup beragam, dapat menggunakan satu parameter dan dua parameter. Model Hargreaves ini memebutuhkan suhu udara rata-rata harian seperti persamaan (13) berikut:

Data cuaca dua parameter

$\mathrm{ET}_{\mathrm{p}}=0.0023 \mathrm{Ra}\left(\sqrt{T_{\max }-T_{\min }}\right)\left(T_{\max }+\right.$ 17.8)

Keterangan:

$\mathrm{ET}_{\mathrm{p}}=$ evapotranspirasi potensial (mm/hari)

$\mathrm{T}_{\max }=$ suhu udara maksimum harian $\left({ }^{\circ} \mathrm{C}\right)$

$\mathrm{T}_{\min }=$ suhu udara minimum harian $\left({ }^{\circ} \mathrm{C}\right)$

$\mathrm{T}_{\text {mean }}=$ suhu udara rata-rata harian $\left({ }^{\circ} \mathrm{C}\right)$

$\mathrm{Ra}=$ radiasi matahari extraterestrial $\left(\mathrm{MJ} \mathrm{m}^{-2}\right.$ hari $^{-1}$ )

Nilai Ra biasanya diprediksi dari posisi lintang tempat dan waktu pengukuran. Adapun persamaan yang digunakan adalah sebagai berikut:

$d_{r}=1+0.33 \cos (0.0172 J)$ $\varphi=\frac{\pi \mathrm{L}}{180}$

$\delta=0.409 \sin (0.0172 \mathrm{~J}-1.39)$

$\omega_{\mathrm{S}}=\arccos [-\tan (\varphi) \tan (\delta)]$

$\mathrm{R}_{\mathrm{a}}=$

$37.6 d_{r}\left[\omega_{S} \sin (\varphi) \sin (\delta)+\cos (\varphi) \cos (\delta) \sin \left(\omega_{s}\right)\right]$

Keterangan:

$\mathrm{d}_{\mathrm{r}} \quad=$ jarak relatif bumi dan matahar

$\mathrm{J} \quad=$ julian day (hari)

$\varphi \quad=$ posisi lintang dalam satuan radian

$\delta=$ deklinasi matahari

$\omega_{\mathrm{S}} \quad=$ sudut jam matahari

Posisi lintang dalam satuan radian untuk lintang selatan (LS) bernilai negatif dan lintang utara (LU) bernilai positif. Adapun apabila data cuaca yang tersedia dua parameter, maka model Hagreaves dapat dihitung dengan persamaan berikut:

$\mathrm{ET}_{\mathrm{p}}=0.0135\left(T_{\text {mean }}+\right.$

$17.78) R_{s}\left(\frac{238.8}{595.5-0.55 T_{\text {mean }}}\right)$

Keterangan:

$\mathrm{ET}_{\mathrm{p}}=$ evapotranspirasi potensial (mm/hari)

$\mathrm{T}_{\text {mean }}=$ suhu udara rata - rata harian $\left({ }^{\circ} \mathrm{C}\right)$

$\mathrm{R}_{\mathrm{s}} \quad=$ radiasi matahari $\left(\mathrm{MJ} / \mathrm{m}^{2} /\right.$ hari $)$

\section{Metode Makkink}

Metode makkink membutuhkan 2 data cuaca yaitu suhu udara rata-rata harian dan radiasi matahari total untuk memprediksi $\mathrm{ET}_{\mathrm{p}}$ secara langsung. Adapun persamaan model ini diberikan oleh persamaan (20) sebagai berikut:

$\mathrm{ET}_{\mathrm{p}}=0.61\left(\frac{\Delta_{m}}{\Delta_{m}+\gamma}\right) \frac{R_{S}}{58.5}-0.12$ 
JSIL | Fausan dkk. : Analisa Model Evaparasi dan Evapotranspirasi Menggunakan Pemadelan Matematika pada Visual Basic di Kabupaten Maros

Keterangan:

$\mathrm{ET}_{\mathrm{p}}=$ evapotranspirasi potensial (mm/hari)

$\mathrm{R}_{\mathrm{s}} \quad=$ radiasi matahari $\left(\mathrm{MJ} / \mathrm{m}^{2} /\right.$ hari $)$

$\Delta_{m} \quad=$ kemiringan garis fungsi tekanan uap jenuh $\left(\mathrm{mb} /{ }^{\circ} \mathrm{C}\right)$

$\gamma \quad=$ konstanta psikometrik $\left(\mathrm{mb} /{ }^{\circ} \mathrm{C}\right)$

Besar nilai $\Delta_{m}$ sebagai berikut:

$\Delta_{m}=$

$33.8639\left[0.05904\left(0.00738 T_{\text {mean }}+\right.\right.$

$\left.0.8072)^{7}-0.0000342\right]$

Nilai $\gamma$ dihitung dengan persamaan berikut ini:

$\mathrm{p}=101.3\left(\frac{293-0.0065 z}{293}\right)^{5.26}$

$\gamma=0.665 \times 10^{-3} \mathrm{P}$

Keterangan:

$\mathrm{z} \quad=$ ketinggian diatas permukaan air laut tempat pengukuran (m)

$\mathrm{P} \quad=$ tekanan atmosfer $(\mathrm{kPa})$

$\mathrm{N}=\frac{24}{\pi} \omega_{\mathrm{s}}$

$\mathrm{N}=\left(0.25+0.5 \frac{\mathrm{n}}{\mathrm{N}}\right) \mathrm{R}_{\mathrm{a}}$

Keterangan:

$\mathrm{N}=$ maksimum lama penyinaran (jam/hari)

$\omega_{\mathrm{s}} \quad=$ sudut jam matahari

$\mathrm{n} \quad=$ lama penyinaran aktual (jam/hari)

\section{Model Turc}

Model Turc membutuhkan 2 data cuaca yaitu suhu udara rata-rata harian dan radiasi matahari total untuk memprediksi ETp secara langsung. Adapun persamaan model ini diberikan oleh persamaan (26) sebagai berikut:

$\mathrm{ET}_{\mathrm{p}}=0.013\left(\frac{\mathrm{T}_{\text {mean }}}{\mathrm{T}_{\text {mean }}+15}\right)\left(\mathrm{R}_{\mathrm{s}}+50\right)$
Keterangan:

$\mathrm{ET}_{\mathrm{p}}=$ evapotranspirasi potensial (mm/hari)

$\mathrm{T}_{\text {mean }}=$ suhu udara rata-rata harian $\left({ }^{\circ} \mathrm{C}\right)$

$\mathrm{R}_{\mathrm{S}} \quad=$ radiasi matahari (ly/hari)

Untuk menyeragamkan unit satuan Rs menjadi $\mathrm{MJ} / \mathrm{m}^{2} /$ hari maka unit satuan Rs perlu dikonversi sehingga persamaan diatas dapat dirubah menjadi berikut:

$\mathrm{ET}_{\mathrm{p}}=0.013\left(\frac{\mathrm{T}_{\text {mean }}}{\mathrm{T}_{\text {mean }}+15}\right)\left(\mathrm{R}_{\mathrm{s}}(23.88)+50\right)$

\section{Model Jensesn-Haise}

Model Jensen-Heise ini membutuhkan beberapa data cuaca yaitu suhu udara rata-rata harian, suhu udara maksimum harian, suhu udara minimum harian dan radiasi matahari total untuk memprediksi ETp secara langsung. Adapun persamaan model ini diberikan oleh persamaan (28) sebagai berikut:

$\mathrm{ET}_{\mathrm{p}}=\mathrm{C}_{\mathrm{T}}\left(\mathrm{T}_{\text {mean }}-\mathrm{T}_{\mathrm{x}}\right) \mathrm{R}_{\mathrm{s}}$

Keterangan:

$\mathrm{ET}_{\mathrm{p}}=$ evapotranspirasi potensial (mm/hari)

$\mathrm{T}_{\text {mean }}=$ suhu udara rata-rata harian $\left({ }^{\circ} \mathrm{C}\right)$

$\mathrm{R}_{\mathrm{s}} \quad=$ radiasi matahari $(\mathrm{mm} / \mathrm{hari})$

$\mathrm{ET}_{\mathrm{p}}=\mathrm{C}_{\mathrm{T}}\left(\mathrm{T}_{\text {mean }}-\mathrm{T}_{\mathrm{x}}\right) \frac{\mathrm{R}_{\mathrm{s}}}{2.25}$

$\mathrm{C}_{\mathrm{T}}, \mathrm{T}_{\mathrm{x}}$ adalah fungsi dari tekanan uap jenuh yang dihitung suhu udara maksimum dan minimum harian.

\section{Model Penman}

Model penman membutuhkan empat parameter data cuaca, yaitu suhu udara, radiasi matahari, kelembaban relatif, kecepatan angin sehingga persamaan (30) model ini dapat diberikan sebagai berikut: 


$$
\mathrm{ET}_{\mathrm{p}}=\mathrm{c}\left(\frac{\mathrm{WR}_{\mathrm{n}}}{2.45}+(1-\mathrm{W}) \mathrm{f}(\mathrm{u})(\mathrm{ea}-\mathrm{ed})\right)
$$

Keterangan:

$$
\begin{aligned}
\mathrm{ET}_{\mathrm{p}}= & \text { evapotranspirasi potensial } \\
& (\mathrm{mm} / \text { hari }) \\
\mathrm{W}= & \text { faktor pemberat yang berkaitan } \\
& \text { dengan suhu } \\
= & \text { radiasi netto ekivalen evaporasi } \\
& \left(\mathrm{MJ} / \mathrm{m}^{2} / \mathrm{hari}\right) \\
\mathrm{R}_{\mathrm{n}} & \\
\mathrm{F}(\mathrm{u})= & \text { fungsi yang berkaitan dengan } \\
& \text { kecepatan angin } \\
\text { Ea-ed = } & \text { perbedaan antara tekanan uap } \\
& \text { jenuh pada suhu udara rata-rata } \\
& \text { dengan tekanan uap aktual rata- } \\
& \text { rata udara (mb) }
\end{aligned}
$$

Nilai $R_{n}$ dapat dihitung berdasarkan persamaan-persamaan berikut:

$$
\begin{aligned}
& \mathrm{R}_{\mathrm{n}}=(1-\alpha) \mathrm{R}_{\mathrm{s}}-\mathrm{R}_{\mathrm{nl}} \\
& \mathrm{R}_{\mathrm{nl}}=\alpha\left(\frac{\mathrm{T}_{\max }-\mathrm{T}_{\min }}{2}\right)(0.34- \\
& \left.0.14 \sqrt{\mathrm{e}_{\mathrm{a}}}\right)\left(1.35 \frac{\mathrm{R}_{\mathrm{s}}}{\mathrm{R}_{\mathrm{so}}}-0.35\right) \\
& \mathrm{R}_{\text {so }}=0.75 \mathrm{R}_{\mathrm{a}} \\
& \mathrm{e}_{\mathrm{a}}=\left(\frac{\mathrm{RH}_{\text {mean }}}{100}\right)\left(\frac{\mathrm{e}^{\circ}\left(\mathrm{T}_{\max }\right)+\mathrm{e}^{\circ}\left(\mathrm{T}_{\min }\right)}{2}\right) \\
& \mathrm{e}^{\circ}(\mathrm{T})=0.6108\left(\frac{17.27 \mathrm{~T}}{\mathrm{~T}+237.3}\right)
\end{aligned}
$$

Keterangan:

$$
\begin{aligned}
\mathrm{R}_{\mathrm{nl}}= & \text { radiasi gelombang panjang } \\
& \text { netto } \\
\mathrm{R}_{\mathrm{so}}= & \text { radiasi clear-sky } \\
\mathrm{ea} \quad= & \text { tekanan uap aktual }(\mathrm{kPa}) \\
\mathrm{RH}_{\text {mean }}= & \text { kelembaban relatif } \\
& \text { rata-rata }(\%) \\
\mathrm{e}^{\circ} \quad & \text { tekanan uap jenuh pada suhu } \\
& \text { udara tertentu }(\mathrm{kPa}) \\
\alpha \quad= & \text { albedo atau koefisien refleksi } \\
& \text { kanopi sesuai tanaman }
\end{aligned}
$$

Nilai fu dan (ea-ed) dapat dihitung berdasarkan persamaan - persamaan berikut: $f(u)=0.27\left(1+\frac{8.64 u}{100}\right)$

$\mathrm{e}_{\mathrm{a}}=0.0478 \mathrm{~T}_{\text {mean }}{ }^{2}-0.823 \mathrm{~T}_{\text {mean }}+$

13.41

$\mathrm{e}_{\mathrm{d}}=\mathrm{e}_{\mathrm{a}}\left(\frac{\mathrm{RH}}{100}\right)$

Keterangan:

$\mathrm{u} \quad=$ kecepatan angin $(\mathrm{m} / \mathrm{s})$

$\mathrm{R}_{\text {so }} \quad=$ radiasi clear-sky

\section{Model Penman-Monteith}

Model ini juga membutuhkan empat parameter data cuaca seperti model Penman sebelumnya dengan persamaan (39) sebagai berikut:

$$
\mathrm{ET}_{\mathrm{p}}=\frac{0.408 \Delta\left(\mathrm{R}_{\mathrm{n}}-\mathrm{G}\right)+\gamma_{\overline{\mathrm{T}_{\text {mean }}+273}} \mathrm{u}\left(\mathrm{e}_{\mathrm{s}}-\mathrm{e}_{\mathrm{a}}\right)}{\Delta+\gamma(1+0.34 \mathrm{u})}
$$

Keterangan:

$$
\begin{aligned}
\mathrm{ET}_{\mathrm{p}}= & \text { evapotranspirasi potensial } \\
& (\mathrm{mm} / \text { hari }) \\
\Delta & = \\
& \text { Kurva kemiringan tekanan uap } \\
& \left(\mathrm{kPa} /{ }^{\circ} \mathrm{C}\right) \\
\mathrm{G}= & \text { flux panas tanah }\left(\mathrm{MJ} / \mathrm{m}^{2} / \mathrm{hari}\right) \\
\mathrm{E}_{\mathrm{a}}= & \text { tekanan uap jenuh }(\mathrm{kPa})
\end{aligned}
$$
berikut:

Nilai $\Delta$ dihitung dengan persamaan

$$
\Delta=\frac{4098(0.6108) \exp \left(\frac{17.27 T_{\text {mean }}}{T_{\text {mean }}+237.3}\right)}{\left(T_{\text {mean }}+237.3\right)^{2}}
$$

Nilai G pada periode siang hari diperkirakan menjadi:

$\mathrm{G}=0.1 \mathrm{R}_{\mathrm{n}}$

Pada periode malam hari, persamaan $\mathrm{G}$ bisa diperkirakan menjadi:

$\mathrm{G}=0.5 \mathrm{R}_{\mathrm{n}}$

Nilai $e_{s}$ dihitung dengan persamaan berikut: 
JSIL | Fausan dkk. : Analisa Model Evaparasi dan Evapotranspirasi Menggunakan Pemadelan Matematika pada

$\mathrm{e}_{\mathrm{s}}=\frac{\mathrm{e}^{\circ}\left(\mathrm{T}_{\max }\right)+\mathrm{e}^{\circ}\left(\mathrm{T}_{\min }\right)}{2}$

\section{HASIL DAN PEMBAHASAN}

\section{Evaporasi}

Faktor yang mempengaruhi evaporasi yaitu faktor fisik dan faktor meteorologis. Faktor fisik meliputi kualitas air, bentuk, luas dan kedalaman air sedangkan faktor meteorologis meliputi radiasi matahari, suhu udara, kelembaban, tekanan udara, dan angin. Jumlah radiasi matahari potensial yang dapat menguapkan air di permukaan tergantung pada lokasi dan waktu. Selain itu, sehubungan dengan perbedaan posisi matahari, maka radiasi matahari potensial juga bervariasi tergantung pada posisi lintang dan musim. Hasil perhitungan evaporasi di daerah Kabupaten Maros dapat dilihat pada Tabel 4.

Tabel 4 Nilai Minimum, Maksimum, Rata-rata, dan Deviasi

\begin{tabular}{lccccccc}
\hline Nilai & $\mathrm{Tn}\left({ }^{\circ} \mathrm{C}\right)$ & $\mathrm{Tx}\left({ }^{\circ} \mathrm{C}\right)$ & $\mathrm{Ta}\left({ }^{\circ} \mathrm{C}\right)$ & $\mathrm{RH}(\%)$ & $\mathrm{R}(\mathrm{mm})$ & $\begin{array}{c}\mathrm{SS} \\
(\mathrm{jam})\end{array}$ & $\mathrm{U}(\mathrm{m} /$ detik) \\
\hline Minimum & 19.00 & 26.25 & 24.10 & 46.00 & 0.00 & 0.00 & 2.00 \\
Rata-rata & 23.90 & 32.02 & 27.58 & 77.28 & 5.35 & 7.65 & 4.96 \\
Maksimum & 26.20 & 38.30 & 30.90 & 97.00 & 133.00 & 11.50 & 12.00 \\
Deviasi & 1.38 & 1.67 & 1.14 & 9.87 & 14.00 & 3.43 & 1.24 \\
\hline
\end{tabular}

Suhu udara sangat mempengaruhi aktifitas manusia dan mahluk hidup yang lain seperti pada Tabel 4, Suhu udara rata-rata dari suhu minimum, suhu ratarata, dan suhu maksimum berturut turut adalah $23.90^{\circ} \mathrm{C}, 32.02^{\circ} \mathrm{C}$, dan $27.58^{\circ} \mathrm{C}$. Keadaan panas udara di Kabupaten Maros di sebabkan oleh panas matahari Radiasi matahari yang diserap oleh atmosfer dan panas yang diemisikan bumi dapat meningkatkan suhu udara sehingga menghasilkan suhu yang tinggi. Pada tekanan atmosfer, semakin tinggi suhu, semakin rendah kandungan uap airnya. Kelembaban udara maksimum di Kabupaten Maros yang dihasilkan sebesar $97.00 \%$ dengan standar deviasi 9.87.

Kelembaban udara ini juga mempengaruhi proses evapotranspirasi tanaman dan kandungan uap air di udara berubah-ubah bergantung pada suhu udara dan tekanan udara. Selain itu,
Kecepatan angin sangat mempengaruhi proses penguapan pada permukaan dimana kecepatan angin yang tinggi menyebabkan turbulensi udara, sehingga jumlah air yang menguap dari permukaan semakin besar. Kecepatan angin bergerak dari tempat bertekanan udara tinggi ke bertekanan udara rendah. Seperti pada Tabel 4, kecepatan angin maksimum yang dihasilkan sebesar $11.50 \mathrm{~m} /$ detik yang terjadi pada tanggal 10 Mei 2019. Parameter yang memiliki standar deviasi terkecil adalah suhu udara rata-rata (Ta). Model-model evaporasi yang digunakan adalah model Penman, Priestley, Bruin, dan Valiantzas. Dalam penelitian ini, model Penman pada evaporasi akan dibandingkan dengan model evaporasi lainnya (Priestley, Bruin, dan Valiantzas). Hasil perhitungan kodingan model-model tersebut akan dituangkan dalam grafik seperti pada Gambar 2. 


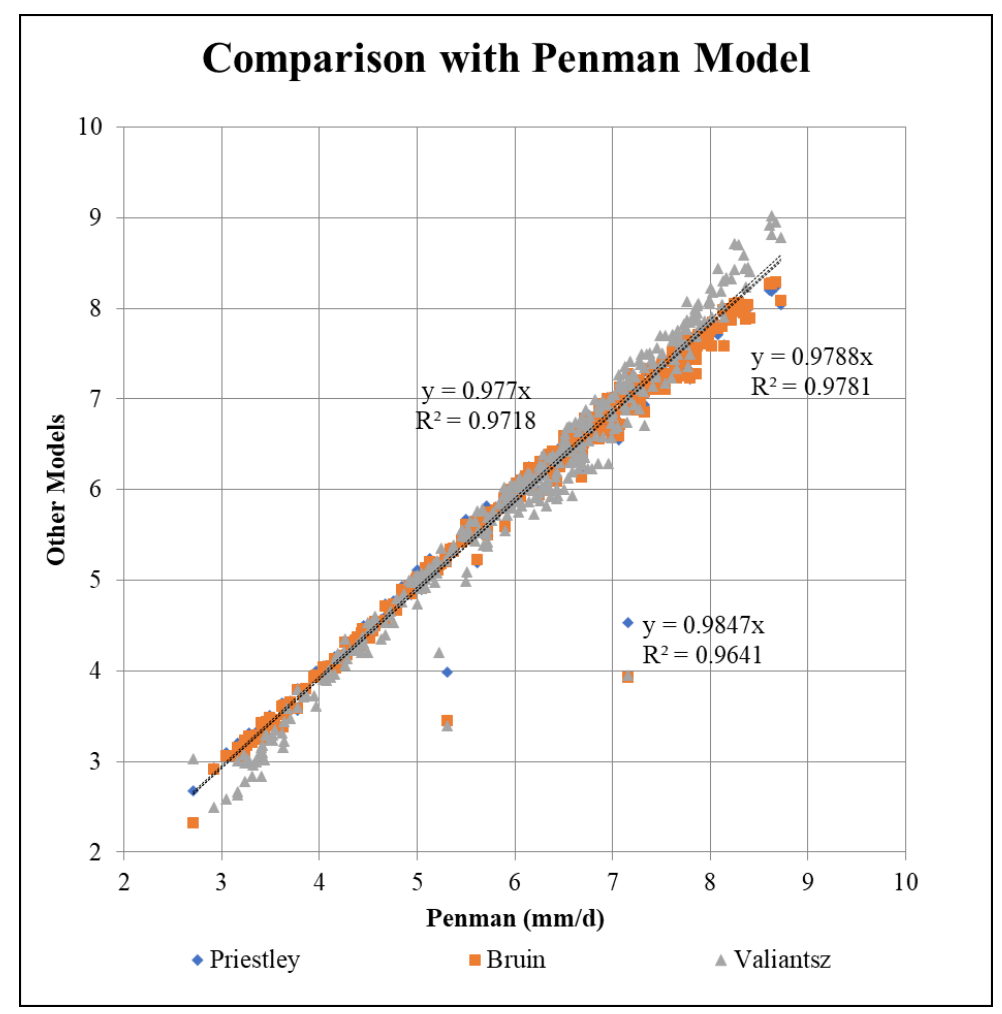

Gambar 2 Perbandingan Dengan Model Penman

Tabel 5 Nilai Model-model

Evapotranspirasi di Kabupaten Maros

\begin{tabular}{lccc}
\hline \multirow{2}{*}{ Parameter } & \multicolumn{3}{c}{ Eo (mm/hari) } \\
\cline { 2 - 4 } & Priestley & Bruin & Valiantzas \\
\hline $\mathrm{R}^{2}$ & 0.980 & 0.973 & 0.967 \\
$\mathrm{SSE}$ & 0.236 & 0.266 & 0.297 \\
\hline
\end{tabular}

Berdasarkan Gambar 2, ketiga model tersebut memiliki Jumalah galat kuadrat (sum of quadrate errors, SSE). SSE adalah perhitungan statistik awal yang dipakai untuk menghitung nilai lain. Nilai SSE dihitung berdasarkan sekumulan data dalam bentuk tabel (Microsoft Excel). Nilai SSE didapatkan dari perbandingan evaporasi model Penman dengan model lainnya (Priestley, Bruin, dan Valiantzas). Nilai SSE ketiga model tersebut berturut turur adalah 0.236, 0.266, dan 0.297 (Tabel 5). Semakin kecil nilai SSE, maka datanya semakin akurat sehingga model yang memiliki nilai SSE terkecil adalah model Priestley yaitu 0.236. Nilai SSE mempengaruhi jumlah data (n). semakin besar nilai $\mathrm{n}$, maka semakin sulit untuk menghasilkan nilai SSE yang kecil.

Tiga dari empat model kombinasi (Priestley-Taylor, DeBruin-Keijman, Penman) memberikan nilai standar deviasi yang berbeda-beda. Selain itu, nilai SSE berbanding terbalik dengan koefisien determinasi $\left(\mathrm{R}^{2}\right)$ yang dapat dilihat pada Gambar 1. Nilai $\mathrm{R}^{2}$ pada ketiga model tersebut berturut-turut adalah 0.980, 0.973, dan 0.967 (Tabel 5). Model yang memiliki nilai $\mathrm{R}^{2}$ terbesar adalah model Priestley. Model yang paling akurat adalah model yang memiliki nilai $\mathrm{R}^{2}$ yang mendekati nilai 1 . Berdasarkan hasil, Perbandingan model Penman dengan model Priestley merupakan model yang paling akurat dengan model lainnya (Bruin dan Valiantzas) dengan nilai 0.980 . 
JSIL | Fausan dkk. : Analisa Model Evaporasi dan Evapotranspirasi Menggunakan Pemodelan Matematika pada Visual Basic di Kabupaten Maras

Tabel 6 Nilai Evaporasi Model Penman, Priestley, Bruin, dan Valiantzas

\begin{tabular}{lcccc}
\hline Evaporasi & $\begin{array}{c}\text { Penman } \\
(\mathrm{mm} / \text { hari })\end{array}$ & Priestley (mm/hari) & Bruin (mm/hari) & Valiantzas (mm/hari) \\
\hline Minimum & 2.7 & 2.7 & 2.3 & 2.5 \\
Maksimum & 8.7 & 8.2 & 8.3 & 9.0 \\
Rata-rata & 6.1 & 6.0 & 6.0 & 6.0 \\
\hline
\end{tabular}

Berdasarkan Tabel 6, nilai evaporasi minimum dari keempat model (Penman. Priestley, Bruin, dan Valiantzas) berturut-turut adalag 2.7 $\mathrm{mm} /$ hari, $2.7 \mathrm{~mm} /$ hari, $2.3 \mathrm{~mm} /$ hari dan $2.5 \mathrm{~mm} /$ hari. Nilai evaporasi minimum dalam setahun di Kabupaten Maros pada model Penman dan Priestley adalah sama yaitu $2.7 \mathrm{~mm} /$ hari. Nilai evaporasi maksimum yang dihasilkan mempengaruhi nilai SSE yaitu semakin besar nilai evaporasi, nilai SSE semakin besar (Valiantz). Nilai yang dihasilkan pada Tabel 6 dapat dibandingkan dengan Tabel 6. Semakin kecil nilai evaporasi maksimum, nilai SSE yang dihasilkan semakin kecil (berbanding lurus) seperti pada model Priestley. Selain itu, nilai evaporasi rata-rata ketiga model (Priestley, Bruin, dan Valiantzas) tersebut adalah sama yaitu $6.0 \mathrm{~mm} /$ hari.

\section{Evapotranspirasi}

Evapotranspirasi adalah suatu gabungan evaporasi dan transpirasi tumbuhan yang hidup di permukaan bumi. Air yang diuapkan oleh tanaman dilepas ke atmosfer. Evaporasi merupakan pergerakan air ke udara dari berbagai sumber seperti tanah, atap, dan badan air. ETa merupakan total air yang menguap dari permukaan baik melalui proses evaporasi maupun transpirasi, sedangkan ETp merupakan potensi dari kemampuan dari atmosfer untuk menguapkan air dari permukaan baik melalui proses evaporasi dan transpirasi. Berdasarkan hasil perhitungan data iklim Kabupaten Maros, nilai minimum, maksimum, rata-rata, dan deviasi disajikan pada Tabel 7.

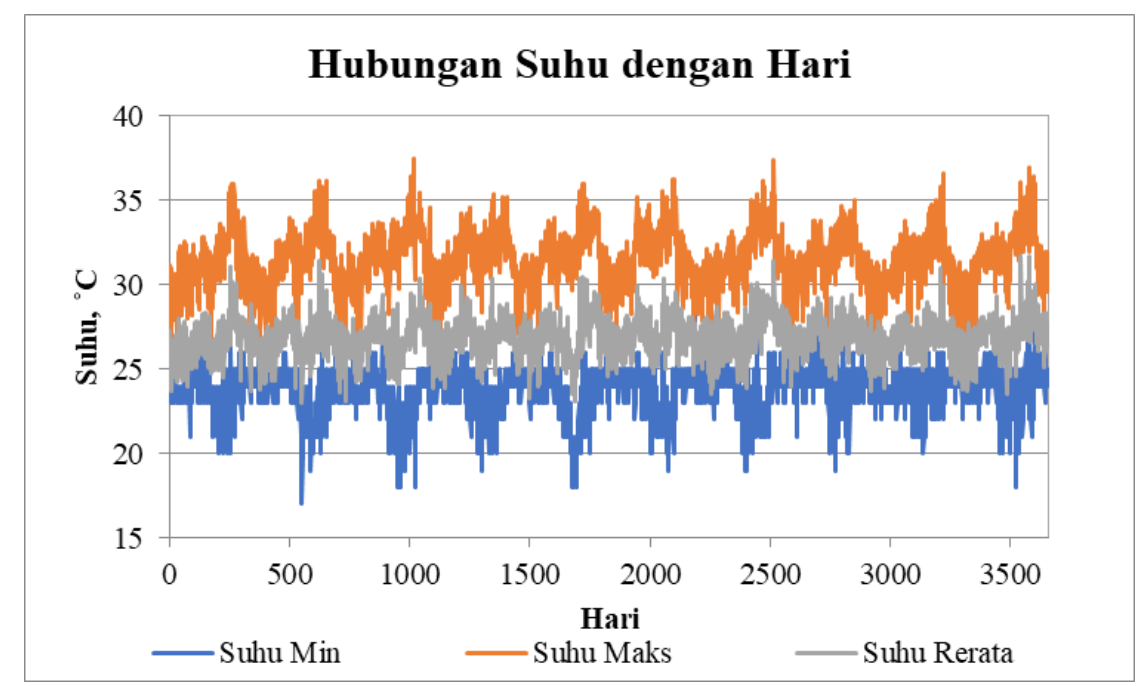

Gambar 3 Suhu Harian Kabupaten Maros 


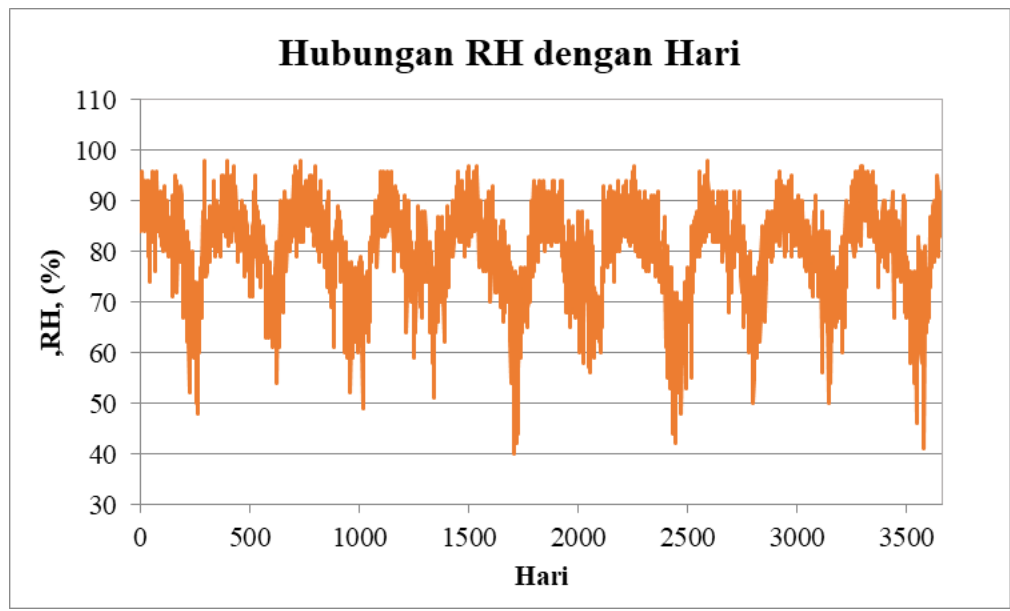

Gambar 4 Kelembaban Relatif Kabupaten Maros

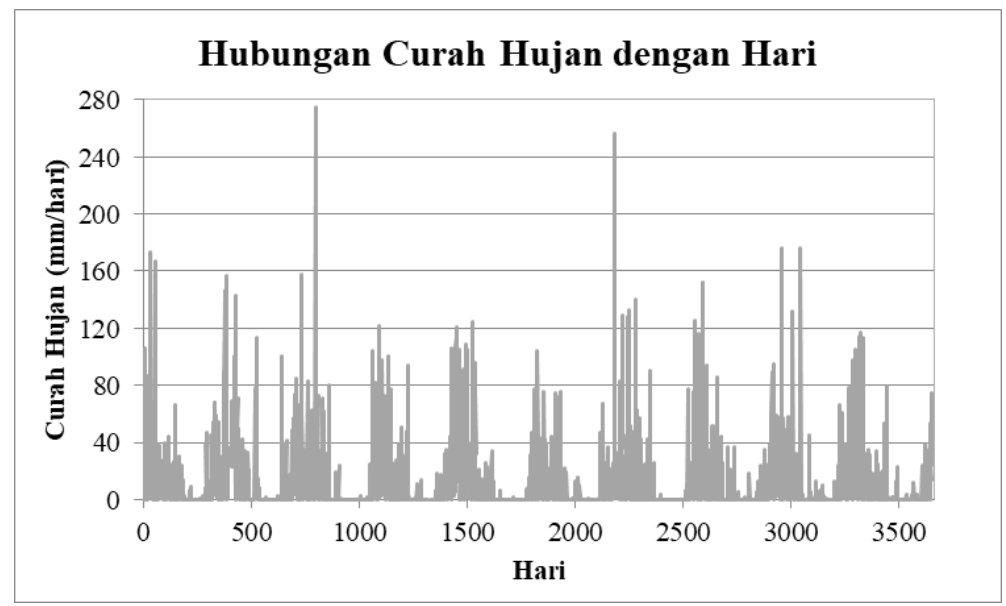

Gambar 5 Curah Hujan (R) Kabupaten Maros

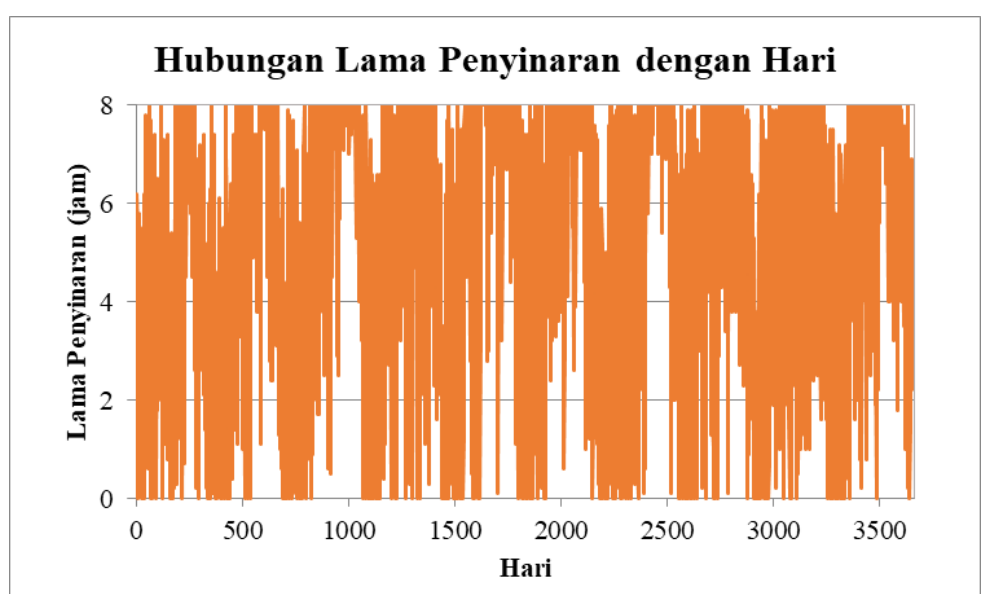

Gambar 6 Lama Penyinaran Matahari (SS) Kabupaten Maros 


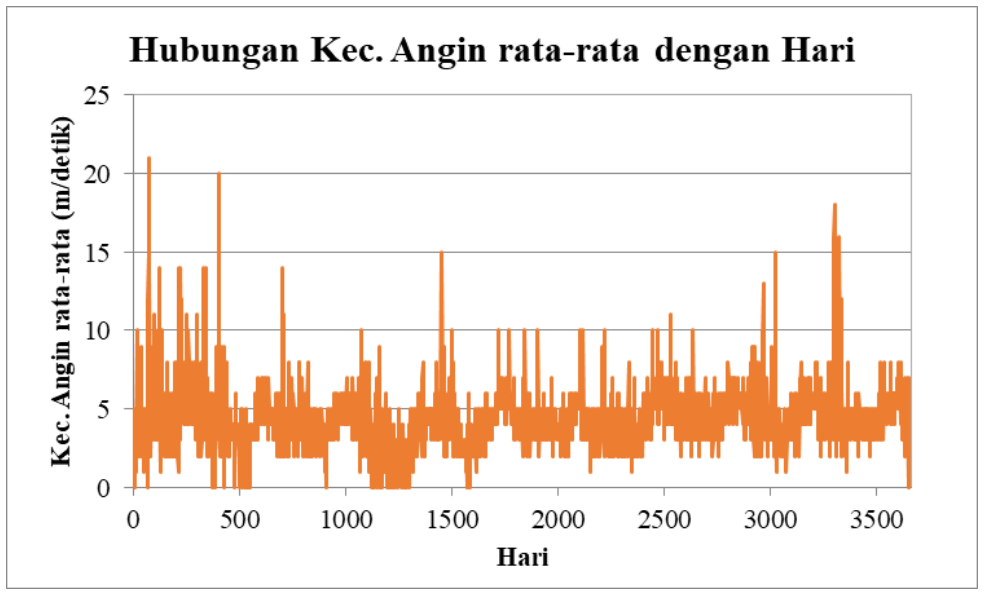

Gambar 7 Kecepatan Angin Kabupaten Maros

Data parameter iklim hasil pengamatan yaitu suhu, kelembaban relatif (RH), curah hujan (R), lama penyinaran matahari (SS), dan kecepatan angin (U), digunakan untuk menghitung evapotranspirasi potensial di Kabupaten Maros. Penelitian ini menggunakan data dari BMKG selama sepuluh tahun yaitu mulai dari tahun 2000 hingga 2009 atau selama 3653 hari dengan sembilan model evapotranspirasi yang digunakan dalam perhitungan. Untuk mendapatkan model evapotranspirasi yang efisien yakni model dengan masukan parameter sedikit dan proses perhitungan tidak rumit, maka dilakukan pembandingan antar model sedangkan untuk mengetahui hubungan antar model digunakan tolok ukur koefisien determinasi $\left(\mathrm{R}^{2}\right)$ yang terdapat pada Tabel 8.

Tabel 7 Nilai minimum, maksimum, rata-rata, dan deviasi

\begin{tabular}{lccccccc}
\hline \multicolumn{1}{c}{ Nilai } & $\operatorname{Tn}\left({ }^{\circ} \mathrm{C}\right)$ & $\mathrm{Tx}\left({ }^{\circ} \mathrm{C}\right)$ & $\mathrm{Ta}\left({ }^{\circ} \mathrm{C}\right)$ & $\mathrm{RH}(\%)$ & $\mathrm{R}(\mathrm{mm})$ & $\mathrm{SS}(\mathrm{jam})$ & $\mathrm{U}(\mathrm{m} /$ detik $)$ \\
\hline Minimum & 17.00 & 25.20 & 23.00 & 40.00 & 0.00 & 0.00 & 0.00 \\
Rata-rata & 23.70 & 31.50 & 26.90 & 80.50 & 10.00 & 5.30 & 4.40 \\
Maksimum & 29.00 & 37.50 & 31.70 & 98.00 & 275.00 & 8.00 & 21.00 \\
Deviasi & 1.40 & 1.70 & 1.10 & 8.60 & 22.20 & 2.70 & 1.80 \\
\hline
\end{tabular}

Berdasarkan Tabel 7, curah hujan maksimum yang didapatkan $275.00 \mathrm{~mm}$ yang terjadi pada tanggal 27 Maret 2003. Kecepatan angin (U) yang dihasilkan sebesar $21.00 \mathrm{~m} /$ detik. Hal ini menunjukkan kecepatan yang besar. Standar deviasi yang dihasilkan setiap parameter seperti temperatur minimum (Tn), temperatur maksimum (Tx), temperatur udara $(\mathrm{Ta})$, kelembaban ratarata $(\mathrm{RH})$, curah hujan $(\mathrm{R})$, lamanya penyinaran matahari (SS), dan kecepatan angin maksimum (U) berturut-turut adalah 1.40, 1.70, 1.10, 8.60, 22.20, 2.70, dan 1.80. Deviasi terbesar yang dihasilkan selama 10 tahun yaitu 2000 2009 adalah RH yaitu 22.20 sedangkan deviasi terkecil yang dihasilkan adalah Ta dengan nilai 1.10. Hasil ini sebagai parameter utama dalam menentukan nilai evapotranspirasi daerah Kabupaten Maros dengan menggunakan sembilan model yaitu Blaney-Cridlle, Linacre, Kharrufa, Remanenko, Hagreaves, Makkink, Turc, Jensen-Haise, dan Penman. Secara sederhana, hasil perhitungan visual basic comparison model dan $\mathrm{R}^{2}$ dan SSE disajikan pada gambar dan tabel berikut. 


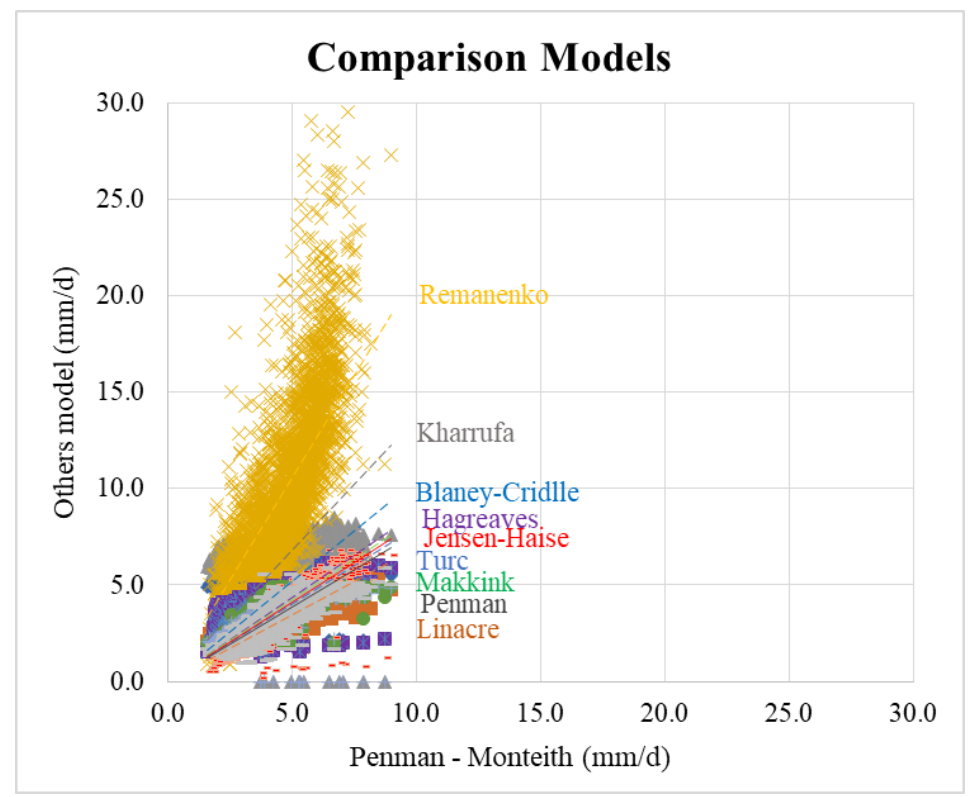

Gambar 8 Comparison Model Evapotranspirasi

Tabel 8 Nilai $\mathrm{R}^{2}$ dan SSE Sembilan Model

\begin{tabular}{|c|c|c|}
\hline Model & $\mathrm{R}^{2}$ & SSE \\
\hline Blaney-Cridlle & 0.008 & 1.367 \\
\hline Linacre & 0.313 & 1.655 \\
\hline Kharrufa & 0.040 & 2.476 \\
\hline Remanenko & 0.575 & 6.159 \\
\hline Hagreaves & 0.771 & 0.857 \\
\hline Makkink & 0.781 & 0.890 \\
\hline Turc & 0.733 & 1.059 \\
\hline Jensen-Haise & 0.889 & 0.963 \\
\hline Penman & 0.810 & 1.156 \\
\hline
\end{tabular}

Gambar 8 menunjukkan comparison model atau perbandingan model antara Penman-Monteith dengan sembilan model lainnya selama 10 tahun (2000 - 2009). Nilai SSE dari sembilan model tersebut dapat dilihat pada Tabel 8. Nilai SSE adalah perhitungan statistik awal yang dipakai untuk menghitung nilai lain seperti jika memiliki sekumpulan data, hubungan antara angka-angka dalam data tersebut dapat dicari. Nilai SSE terbesar adalah Remanenko yaitu 6.159 sedangkan nilai SSE terkecil adalah Hagreaves dengan nilai 0.857. Nilai evapotrasnpirasi maksimum yang dihasilkan kesembilan metode tersebut berturut-turut adalah 5.8 $\mathrm{m} /$ hari, $5.9 \mathrm{~mm} /$ hari, $8.5 \mathrm{~mm} /$ hari, 50.8 $\mathrm{mm} /$ hari, $6.2 \mathrm{~mm} /$ hari, $5.9 \mathrm{~mm} /$ hari, 5.0 $\mathrm{mm} /$ hari, $6.8 \mathrm{~mm} /$ hari, dan $5.9 \mathrm{~mm} /$ hari sedangkan nilai evapotranspirasi maksimum pada model PenmanMonteith selama 10 tahun adalah 9.0 $\mathrm{mm} / \mathrm{hari}$.

Berdasarkan data tersebut, model Remanenko merupaka nilai Evapotranspirasi maksimum terbesar dibandingkan dengan delapan metode lainnya. Hal ini menunjukkan bahwa nilai SSE yang dihasilkan juga terbesar dibandingkan dengan model evapotranspirasi lainnya. Nilai evapotranspirasi (ETP) maksimum dengan SSE memiliki hubungan yang 
JSIL | Fausan dkk. : Analisa Model Evaporasi dan Evapotranspirasi Menggunakan Pemodelan Matematika pada

berbanding lurus. Semakin besar nilai $\mathrm{ET}_{\mathrm{P}}$, nilai SSE yang dihasilkan akan semakin besar. Selain nilai SSE, nila $\mathrm{R}^{2}$ dari sembilan model tersebut. Model evapotranspirasi dengan nilai $\mathrm{R}^{2}$ terbesar adalah adalah Jensen-Haise yaitu 0.889 sedangkan nilai $\mathrm{R}^{2}$ terkecil adalah Blaney-Cridlle yaitu 0.008 (sangat kecil).

Nilai koefisien determinasi antara 0 samapai dengan 1 (Riang 2004). Dinamakan koefisien determinasi karena $\mathrm{R}^{2} \times 100 \%$ daripada variasi yang terjadi dalam variabel tak bebas $\mathrm{Y}$ dapat dijelaskan oleh variabel bebas $\mathrm{X}$ dengan adanya regresi linier $\mathrm{Y}$ atas $\mathrm{X}$ (Sujana 2011). Besarnya harga koefisien determinasi adalah berkisar $0<\mathrm{R}^{2}<1$. Artinya jika $\mathrm{R}^{2}$ mendekati 1 maka dapat dikatakan pengaruh variabel bebas terhadap variabel terikat adalah besar (Zain 1995). Berarti model yang digunakan baik untuk menjelaskan pengaruh variabel tersebut. Untuk memastikan tipe hubungan antar variabel dengan berpedoman pada Tabel 9 dengan lima jenis interval koefisien dan tingga hubungan mulai dari sangat rendah, rendah, cukup kuat, kuat dan sangat kuat.

Tabel 9 Interpretasi Koefisien

\begin{tabular}{rl|c}
\hline Interval Koefisien & Tingkat Hubungan \\
\hline 0,80 & 1,000 & Sangat Kuat \\
0,60 & 0,799 & Kuat \\
0,40 & 0,599 & Cukup Kuat \\
0,20 & 0,399 & Rendah \\
0,00 & 0,199 & Sangat Rendah \\
\hline
\end{tabular}

Sumber: (Sujana, 2001)

Berdasarkan hasil secara keseluruhan, koefisien determinasi $\left(\mathrm{R}^{2}\right)$ yang dihasilkan pada model Priestley yaitu 0.967 Jensen-Haise yaitu 0.889 menunjukkan tingkat hubungan yang Sangat Kuat yaitu berada diantara $0.80-$ 1.00 seperti disajikan pada Tabel 9 sehingga dapat dikatakan pengaruh variabel bebas terhadap variabel terikat adalah besar sehingga model yang digunakan baik untuk menjelaskan pengaruh variabel tersebut.

\section{KESIMPULAN}

Simpulan yang dapat ditarik dari penelitian ini sebagai berikut:

1. Pada pemodelan evaporasi, model yang memiliki nilai $\mathrm{R}^{2}$ terbesar adalah model Priestley yaitu 0.980

2. Pada pemodelan evapotranspirasi, model yang memiliki nilai $\mathrm{R}^{2}$ terbesar adalah model JensenHaise yaitu 0.889

3. Kedua model yang memiliki nilai $\mathrm{R}^{2}$ terbesar menunjukkan tingkat hubungan yang Sangat Kuat yaitu berada diantara $0.80-1.00$

\section{DAFTAR PUSTAKA}

Bruin K. 1979. The Priestley-Taylor evaporation model applied to a large shallow lake in the Netherland. Journal of Applied Meteorology. 18 : 898-903.

Capece CL. 2002. Comparison of Evapotranspiration Estimation Methods. Yogyakarta (ID) : Kanisius.

Doorenbos, P. (1977). Guideline fo Predicting Crop Water Requirement. Rome (IT) : FAO.

Penman HL. 1948. Natural evaporation from open water, bare soil and grass. Proceedings of the Royal Society, (pp. 120 - 145).

Priestley T. 1972. On the assessment of surfave heat flux and evaporation using large-scale parameters. Jurnal Monthly Weather Review. 100: 81-92.

Riang MS. 2014. Analisa faktor-faktor yang mempengaruhi hasil produksi padi di Deli Serdang. Saintia Matematika. 2 (1): 71 - 83. 
Rokhma. 2008. Menyelamatkan Pangan dengan Irigasi Hemat. Yogyakarta (ID): Kanisius.

Singh X. 1997. Evaluation and Generalization of 13 Mass-transfer Equations for determining free water evaporation. Hydrological Processes. 11: 311-323.

Sujana. 2001. Metode Statistik. Bandung (ID): Tarsito.

Valiantzas. 2006. Simplified version for the Penman evaporation equation using routine weather data. Journal of Hydrology. 331, 3 - 15.

Zain S. 1995. Ekonometrika Dasar. Jakarta (ID): Erlangga. 
JSIL | Fausan dkk. : Analisa Model Evaporasi dan Evapotranspirasi Menggunakan Pemadelan Matematika pada Visual Basic di Kabupaten Maros 